\title{
Dakwah Islamiah dan Usaha Mengatasi Akhlak yang Buruk
}

\author{
Ahmad Zuhdi \\ Institut Agama Islam Negeri (IAIN) Kerinci \\ zuhdi69@siswa.um.edu.my
}

\begin{abstract}
Islamic Da'wah is essentially conveying divine messages through the Koran to educate mankind apart from learning about existing branches of science, the essential purpose of which is how to shape one's personality, so that they have moral perfection. Akhlakul karimah is a manivestation of the faith and complete Islam of a Muslim. Akhlakul karimah in its broadest sense is behavior, temperament, or adab based on the values of revelation as practiced by the Prophet Muhammad. Akhlakul karimah proved effective in solving a problem as complex as anything. Intellect and conscience of every human being can be seen through the behavior that he usually expresses in daily life. In other words, morals are a unit of measure used to measure the height of one's mind and conscience. Morals will be owned by anyone who truly understands, believes in, and practices the teachings of Islam. And, anyone who succeeded in making akhlakul karimah as a character in him would certainly be the luckiest person, both in the world and in the hereafter. The morality of the generation does not require imagery or even impose the will. For him, shared interests are far more important than their personal and group interests. Businesses and efforts to overcome bad behavior or bad character are joint responsibilities, by carrying out various approaches and methods, individually and collectively, formally and informally. So that a safe and peaceful community mission can be achieved as expected by all.
\end{abstract}

Keywords: Dakwah, Islamiah, Morals

\section{ABSTRAK}

Dakwah Islam hakikatnya adalah menyampaikan pesan pesan samawi melalui al-Quran untuk mendidik umat manusia selain dari pembelajaran tentang cabang-cabang ilmu yang ada, tujuan hakikinya adalah bagaimana upaya membentuk kepribadian seseorang, sehingga mereka memiliki kesempurnaan akhlak. Akhlakul karimah merupakan wujud konkret keimanan dan keislaman paripurna seorang Muslim. Akhlakul karimah dalam arti luas adalah perilaku, perangai, ataupun adab yang didasarkan pada alQuran dan Sunnah sebagaimana yang dipraktikkan oleh Nabi Muhammad SAW. Akhlakul karimah terbukti efektif dalam menuntaskan suatu permasalahan serumit apa pun. Akal dan nurani setiap manusia dapat dilihat dan dinilai melalui tingkah laku yang biasa ia tampakkan dalam keseharian. Dengan kata lain, akhlak merupakan suatu takaran yang digunakan untuk menilai atau mengevaluasi ketinggian akal dan nurani seseorang. Akhlak akan menjadi milik siapa saja yang secara konsisten dan sungguh-sungguh dalam memahami, meyakini, dan mengamalkan ajaran Islam. Siapa saja yang berhasil menjadikan akhlakul karimah sebagai karakter dalam dirinya akan menjadi orang yang paling beruntung, baik di dunia maupun di akhirat. Generasi yang berakhlak tidak memerlukan pencitraan apalagi memaksakan kehendak. Baginya, kepentingan publik jauh lebih penting daripada kepentingan pribadi dan golongannya. Usaha dan upaya mengatasi perilaku buruk atau akhlak buruk merupakan tanggung jawab bersama, dengan melakukan berbagai pendekatan dan cara, secara individu maupun koletif, formal dan nonformal. Sehingga misi keummatan yang aman dan tentram dapat tercapai sebagaimana yang diharapkan oleh semuanya.

Kata Kunci: Dakwah, Islamiah, Akhlak

\section{PENDAHULUAN}

Dakwah Islamiyah merupakan seruan dan ajakan untuk umat ke jalan Allah, dengan berbagai cara dan seni. Cara dan seni tersebut berusaha untuk menghasilkan sesuatu yang boleh memberikan kenikmatan rohaniah, yang dapat memberikan kesenangan dan membahagiakan orang lain. Inilah yang disebutkan dalam firman-Nya: 


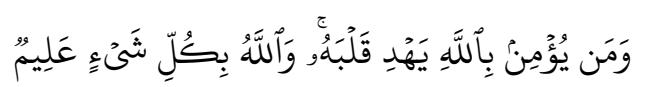

"Dan sesiapa yang beriman kepada Allah, Allah akan memimpin hatinya (untuk menerima apa yang telah berlaku itu dengan tenang dan sabar); dan (ingatlah), Allah Maha mengetahui akan tiap-tiap sesuatu."'(QS. Al-Taghabun 64 : 11)

Disebutkan pula dalam ayat lain:

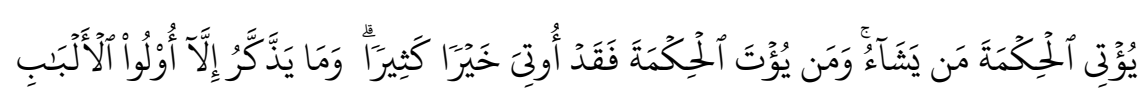

"Allah memberikan hikmah kebijaksanaan (ilmu yang berguna) kepada sesiapa yang dikehendakiNya (menurut aturan yang ditentukanNya). dan sesiapa yang diberikan hikmat itu maka Sesungguhnya ia telah diberikan kebaikan yang banyak. dan tiadalah yang dapat mengambil pengajaran (dan peringatan) melainkan orang-orang yang menggunakan akal fikirannya." (QS.al-Baqarah $2: 269)$

Ayat diatas dapat dipahami bahwa hidayah akan diperoleh dengan sempurna bila seseorang itu benar-benar beriman kepada Allah. Kemudian selalu berkeinginan untuk mengamalkan sepenuhnya. Sehinga dengan mengenal dan mempelajari ajaran Islam melalui dakwah yang disampaikan oleh para da' $i$ dan da'iyah dapat memberikan pencerahan dan perubahan sikap dan perilaku seseorang, atau disebut dengan akhlak. Menurut Salmadanis (2004) da'i berarti orang yang bertugas mengajak manusia kepada agama Islam atau mazhabnya (Sunata, 2017, p. 47).

Akhlak yang senantiasa melekat pada perilaku seseorang menurut norma-norma atau penilaian yang diberikan sesuai perbuatan yang dilakukan tersebut. Perbuatan itu ditentukan pula dengan kriteria-kriteria yang jelas apakah baik atau buruk. Akhlak secara umum merupakan segala bentuk perbuatan manusia yang memiliki ciri-ciri sebagaimana disebutkan di atas, yaitu perbuatan yang dilakukan tanpa paksaan, ia tumbuh dari kehendak dan kemauan diri sendiri. Bila kehendak dan kemauan seseorang bertentangan dengan asas-asas ajaran Islam, yakni al-Quran dan Hadis, maka perilaku tersebut termasuk kedalam akhlak yang buruk. Perilaku buruk yang dilakukan seseorang disebabkan ketidaksanggupannya mengontrol nafsunya, sehingga sulit membedakan antara perbuatan yang baik dan buruk. Padahal perilaku buruk berbahaya bagi dirinya dan juga masyarakat. Lemahnya kesadaran seseorang yang melakukan kemungkaran dan perbuatan keji akan memberikan dampak yang lebih buruk lagi. Semakin lama manusia itu tercengkeram dalam kekuasaan setan, maka semakin jauhlah ia ddengan Allah SWT, maka semakin tebal pula hijab-hijab nafsu dihatinya, seterusnya menghilangkan harapan manusia itu untuk mema'rifatkan dirinya dengan Allah SW'T (Azwan, 1993, p. xv). 
Dalam Islam, manusia sebenarnya merupakan makhluk yang sempurna dan berbeda dengan makhluk lain. Manusia diberi kemuliaan dan kelebihan, sebagaimana disebutkan dalam firman Allah SWT :

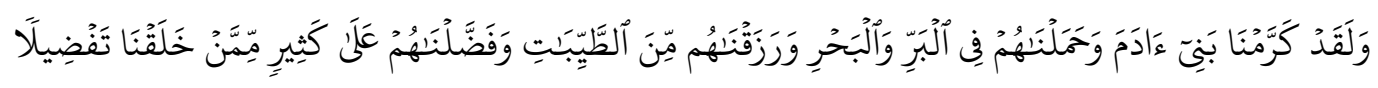

"Dan sesungguhnya telah Kami muliakan anak-anak Adam, Kami angkut mereka di daratan dan di lautan, Kami beri mereka rezeki dari yang baik-baik dan Kami lebihkan mereka dengan kelebihan yang sempurna atas kebanyakan makhluk yang telah Kami ciptakan"'(QS. Al-Isra' $16: 70$ )

Pada ayat yang lain disebutkan pula :

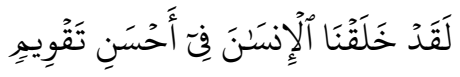

"sesungguhnya Kami telah menciptakan manusia dalam bentuk yang sebaikbaiknya.”(QS. 95 : 4)

Demikian halnya dengan kajian tentang akhlak semakin tumbuh menjadi suatu ilmu yang berdiri sendiri, yaitu ilmu yang memiliki ruang lingkup pembahasan yaitu, tujuan, rujukan aliran dan para tokoh yang mengembangkannya. Berbagai aspek yang terkandung dalam akhlak ini kemudian membentuk satu kesatuan yang saling berkaitan dan membentuk suatu ilmu.

\section{HASIL DAN PEMBAHASAN}

\section{Aktifitas Dakwah yang Dapat merubah Akhlak}

Seiring dengan konsep penyiaran Islam, aktivitas dari seorang pendakwah sebelum melaksanakan tugas mulianya, tentu sangat perlu memperhatikan dan mempelajari tentang strategi ataupun cara berdakwah yang hendak dilakukannya. Seperti M. Natsir yang menyebutkan Agama adalah suatu petunjuk tidak seorangpun yang mampu memberi atau memaksa. Dakwah hanya terbatas pada media informatif. Kita hanya ingin mencoba bahwa “agama adalah pesan”(al-din-al-nasibat) (Natsir, 2000, p. 123). Dijelaskan lagi oleh Nurchalis Madjid; pendakwah hanyalah perantara, penyampai tidak lebih dari itu. Tugas Nabi Muhammad s.a.w pun tidak lebih daripada menyampaikan, yaitu memberi tahu, memperingatkan dan membimbing manusia. keberhasilan atau kegagalan dakwah bukanlah tanggung jawabnya, melainkan tanggung jawab Allah (Madjid, 1993). Hamka pula menjelaskan masyarakat tidak dipaksa buat menerima dakwah, tetapi mereka diajak mendengar. Baik dia raja kuasa, atau dia miskin papa. Sebab sama keadaan datang mereka ke dunia, sama-sama tidak mempunyai apa-apa, dan sama keadaan perginya dari dunia, sama-sama tidak membawa apa-apa (Hamka, 1994, p. 241). A. Hasjmy, juga mengemukakan bahwa tujuan dakwah adalah membentangkan jalan Allah diatas bumi agar dilalui umat manusia (Hasjmy, 1994, p. 18). 
Sebagaimana dalam petunjuk yang diajarkan oleh Allah SWT bagi para pendakwah, ketika menyiarkan Islam, hendaknya menggunakan metode yang efektif, merujuk kepada alQuran:

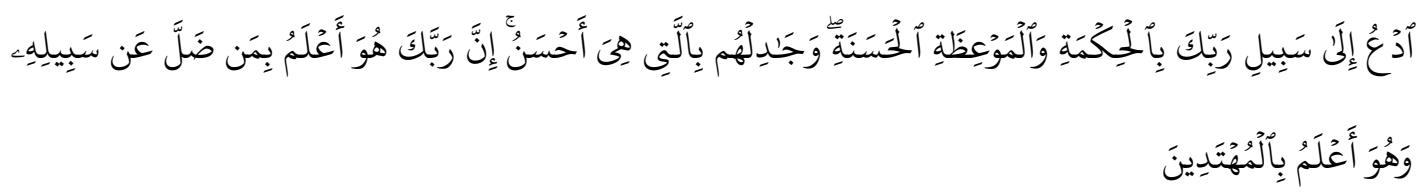

"Serulah ke jalan Tuhanmu (Wahai Muhammad) Dengan hikmat kebijaksanaan dan nasihat pengajaran Yang baik, dan berbahaslah Dengan mereka (yang Engkau serukan itu) Dengan cara Yang lebih baik; Sesungguhnya Tuhanmu Dia lah jua Yang lebih mengetahui akan orang Yang sesat dari jalannya, dan Dia lah jua Yang lebih mengetahui akan orang-orang Yang mendapat hidayah petunjuk."(QS. Al-Nahl 16 : 125).

Ayat tersebut memberikan pemahaman kepada pendakwah bahwa menyiarkan ajaran agama Islam, dengan cara yang hikmah, nasehat dan diskusi dengan baik, kemudian mesti dilakukan dengan bentuk individu dan kolektif atau secara berkelompok agar masyarakat Islam lebih kuat dan bersatu-padu dalam menegakkan amar ma'ruf serta mencegah nahi munkar.

Firman Allah SWT menjelaskan:

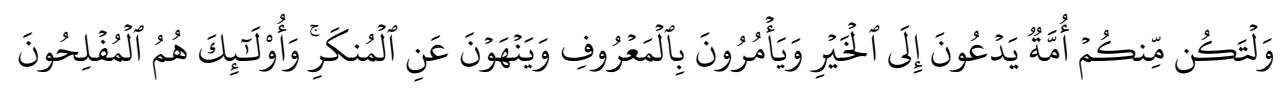

"Dan hendaklah ada di antara kamu satu puak Yang menyeru (berdakwah) kepada kebajikan (mengembangkan Islam), dan menyuruh berbuat Segala perkara Yang baik, serta melarang daripada Segala Yang salah (buruk dan keji). dan mereka Yang bersifat demikian ialah orang-orang Yang Berjaya."(QS. Al-Imran 3 : 104).

Eksistensi pendakwah dalam mendidik umat, tidak mesti dilakukan secara formal melalui institusi atau lembaga yang khas, akan tetapi juga dapat dilakukan secara terbuka dan ditempat dimana umat biasa berkumpul, seperti masjid dan mushalla. Melalui tempat ibadah ini para pendakwah lebih mudah menyampaikan kandungan ajaran Islam untuk diketahui dan diamalkan oleh umat Islam.

Adapun implikasi masjid sebagai lembaga pendidikan Islam, diantaranya; Pertama, mendidik anak untuk taat beribadah kepada Allah. Kedua, menanamkan sikap cinta pada ilmu pengetahuan dan rasa kebersamaan, serta menyadarkan mereka akan hak dan kewajiban sebagai pribadi, sosial, dan warga Negara. Ketiga, memberi rasa ketenangan, kekuatan dan kemakmuran potensi-potensi ruhani manusia melalui pendidikan kesabaran, kesadaran, keberanian, optimisme dan penyelenggaran penelitian (al-Rahlawi, 1979, p. 13). 
Demikian pula Hadari Nawawi (1993) menjelaskan bahwa erat sekali kaitannya dengan pemanfaatan masjid secara maksimal dalam mendidik, masyarakat, orang tua, anak-anak dan pendidik lainnya dapat bersama-sama melakukan kegiatan sebagai berikut: Pertama, menjadikan masjid sebagai langkah awal untuk memasuki kehidupan sehari-hari. Kedua, menjadikan masjid sebagai penutup kesibukan sehari-hari menjelang tidur. Ketiga, menjadikan masjid sebagai tempat untuk mempererat silaturrahim antar sesama muslim. Keempat, menjadikan masjid sebagai tempat membina akhlak dan memahami nilai-nilai kehidupan. pengetahuan agama dan mempersiapkan kader-kader muslim yang unggul (p. 207).

Disinilah peran sebagai pendakwah mengajarkan kepada umat etika dan cara menjalankan aktifitas ibadah, dan berperilaku yang baik. Pendakwah juga harus mampu menanamkan keyakinan umat agar berpegang teguh kepada ajaran Islam dengan patuh kepada Allah dan Rasul-Nya, baik berupa perintah atau yang dilarangnya, mahupun ajaran yang bersifat menghalalkan, menganjurkan amalan sunnah dan makruh. Kemudian menanamkan sikap teguh berdasarkan cinta kepada Allah, bukan kerana rasa takut atau terpaksa. Maksud cinta kepada Allah adalah sentiasa taat kepadaNya dimana saja berada.

\section{Urgensi dan Pesan Dakwah}

Sama halnya dengan tugas pendidikan yang dilakukan oleh seorang pendidik terhadap anak didiknya, maka pendakwah juga demikian adanya, bagaimana keberadaannya dapat diakui dan diterima oleh al-mad'u ketika melaksanakan tugas dakwahnya.

Karakteristik dakwah tidak terlepas dari bagaimana mencerminkan moral dan akhlak individu pendakwah dengan baik. Seperti yang dijelaskan Zakiah Derajat (1985) bahwa Moralitas yang sungguh-sunguh itu adalah: Pertama, kelakuan yang sesuai dengan ukuranukuran masyarakat, yang timbul dari hati sendiri (bukan paksaan dari luar). Kedua, rasa tanggung jawab atas tindakan itu. Ketiga, mendahulukan kepentingan umum daripada keinginan atau kepentingan pribadi (p. 8)

Oleh karena itu, membentuk pendakwah muda yang berkarakter dari madrasah tumpuan utama adalah bagaimana mereka dibekali, di didik dan dilatih mengamalkan ajaran Islam dengan baik serta penampila yang serasi dengan ajaran Islam itu sendiri. akhlak yang mulia yaitu akhlak yang diridai oleh Allah SWT, akhlak yang baik itu dapat diwujudkan dengan mendekatkan diri kita kepada Allah yaitu dengan mematuhi segala perintahnya dan meninggalkan semua larangannya, mengikuti ajaran-ajaran dari sunnah Rasulullah, mencegah diri kita untuk mendekati yang ma'ruf dan menjauhi yang munkar, seperti firman Allah SWT : 


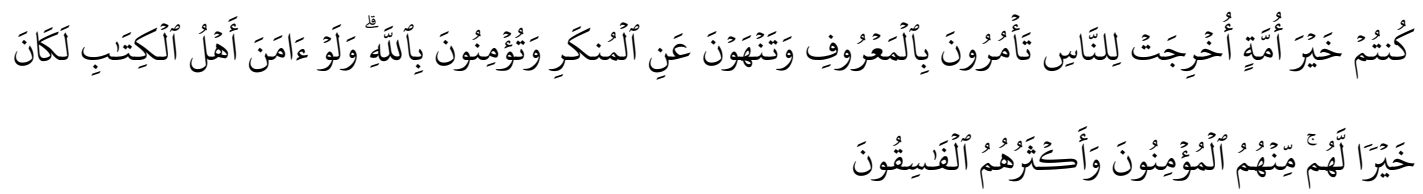

"Kamu adalah umat yang terbaik yang dilahirkan untuk manusia, menyuruh kepada yang ma'ruf, dan mencegah dari yang munkar, dan beriman kepada Allah. Sekiranya Ahli Kitab beriman, tentulah itu lebih baik bagi mereka, di antara mereka ada yang beriman, dan kebanyakan mereka adalah orang-orang yang fasik."(QS. Al-Imran 3 : 110)

Sejak awal, syariat Islam datang untuk mencetak orang menjadi muslim. Menciptakan manusia sejati adalah tujuan terpenting dari dakwah Islam. Yang dimaksud manusia disini adalah manusia yang utuh dan manusia yang memangku kemanusiaan yang sempurna. Bagitu pula halnya pengertian sebenarnya manusia muslim. Jadi sayarat muslim yang hakiki adalah: bertaubid, ittiba')imtitsal) dan tazkiyah. Para pengikut Rasulullah adalah pengganti di dalam mengembankan tugas risalah Rasulullah, kecuali dalam hal kenabian dan kerasulan. Tugastugas para rasul yang juga merupakan kewajiban para pengikutnya dan orang-orang yang mengikuti manhajnya antara lain, berjihad melawan kekafiran, melaksanakan hukum-hukum Allah, berdakwah ke jalan Allah, tabsyir dan inzar. Proses ini akan terwujud secara efektif melalui pendidikan. Melalui pendidikan manusia dapat mengembangkan fitrahnya, baik fisik maupun psikis secara optimal. Dengan pendidikan manusia dapat mempertajam fitrah akal dan mengontrol nafsunya.

Kemudian pendakwah menjelaskan kepada umat tentang pentingnya menjalankan ibadah yang diperintahkan oleh Allah SWT. Ibadah yang diajarkan Islam tersebut adalah ibadah yang melingkupi seluruh aspek kehidupan dan bersifat umum, baik ibadah mahdhah seperti ibadah-ibadah wajib, sholat, zakat, puasa dan haji, maupun ghairu mahdhah sesuai dengan intelegensi manusia yang bertingkat-tingkat, demikian juga potensinya.

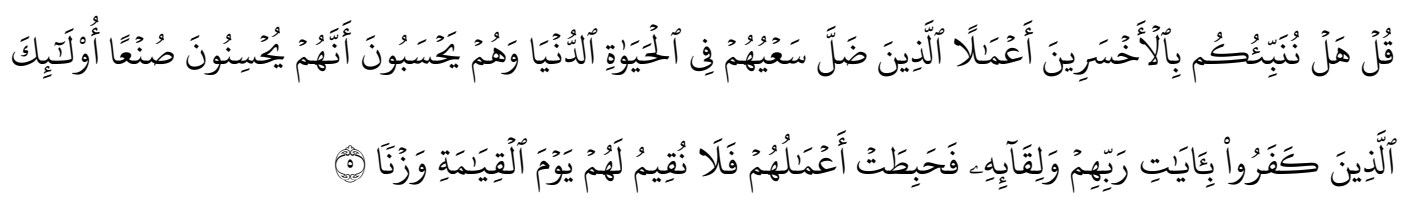

"Katakanlah (Wahai Muhammad): "Mahukah Kami khabarkan kepada kamu akan orang-orang Yang paling rugi amal-amal perbuatannya. (Iaitu) orang-orang Yang telah sia-sia amal usahanya Dalam kehidupan dunia ini, sedang mereka menyangka Bahawa mereka sentiasa betul dan baik pada apa sahaja Yang mereka lakukan, merekalah orang-orang Yang kufur ingkar akan ayat-ayat Tuhan mereka dan akan pertemuan dengannya; oleh itu gugurlah amal-amal mereka; maka akibatya Kami tidak akan memberi sebarang timbangan untuk menilai amal mereka, pada hari kiamat kelak."(QS. Al-Kahfi. 18 : 103-105)

\section{Definisi Akhlak yang Buruk}


Sebelum memberikan definisi tentang hal yang berkaitan dengan akhlak buruk, perlu diketahui bahawa teori yang pernah dikemukakan oleh Lambrosso dan para pengikutnya yang percaya akan adanya manusia yang terlahir sebagai penjahat. Pendapatnya ini telah ditolak oleh para ahli sesuai dengan bidangnya. Seperti Alexis Carrel, seorang sarjana kebangsaan Prancis, yang menyatakan bahwa, manusia yang terlahir sebagai penjahat, seperti dikemukakan oleh Lambrosso tidaklah benar. Yang ada adalah orang yang terlahir dalam keadaan kurang sempurna dan kemudian menjadi penjahat. Pada kenyataannya, kebanyakan penjahat adalah orang-orang normal. Bahkan bias jadi ia lebih pandai dari para polisi dan hakim (Lari, 2006, p. 33).

Oleh karenanya, Al-Ghazali secara cemerlang membedakan beberapa hal mengenai keburukan akhlak yakni: Pertama, keburukan akhlak yang timbul karena ketidaksanggupan seseorang mengendalikan nafsunya, sehingga pelakunya disebut al-jabil( الخاهل). Kedua, perbuatan yang diketahui keburukannya, tetapi ia tidak bisa meninggalkannya karena nafsunya sudah menguasai dirinya, sehingga pelakunya disebut al-jahil al-dallu الحماهل الخّال Ketiga, keburukan akhlak yang dilakukan oleh seseorang, karena pengertian baik baginya sudah kabur, sehingga perbuatan buruklah yang dianggapnya baik. Maka pelakunya disebut al-jabil al-dallu al-fasiq ( (الحاهل الضّالّ الفاسق. Keempat, Perbuatan buruk yang sangat berbahaya terhadap masyarakat pada nya, sedangkan tidak terdapat tanda-tanda kesadaran bagi pelakunya, kecuali hanya kekhawatiran akan menimbulkan pengorbanan yang lebih hebat lagi. Orang yang melakukannya disebut al-jabil al-dallu al-fasiq al-syarir الجاهل الضّال الفاسق الشّرير (Mahjudin, 1991, p. 41).

Apa yang dikemukakan oleh Al-Ghazali, diatas dengan pembagian secara rinci keburukan akhlak hal ini menggambarkan bahwa eksistensi ajaran Islam menghalalkan bagi penguasa/pemimpin untuk memberikan hukuman mati bagi pelakunya, bila metode-metode yang sederhana tidak diindahkan oleh umat atau masyarakat secara kolektif. Tujuannya adalah agar perilaku yang merusak dan mencemarkan tersebut tidak menimbulkan volusi universal. Yang meresahkan masyarakat, bangsa dan negara.

\section{Bentuk - Bentuk Akhlak Buruk}

Ada beberapa bentuk prilaku manusia yang buruk, prilaku yang sedemikian ini tidak harus dibiarkan tumbuh subur, melainkan mesti diobati dan di didik secara ruhiyahnya, agar dapat kembali menjadi manusia yang baik. Diantara bentuk bentuk prilaku buruk tersebut adalah: Pertama Ananiyah, yaitu orang orang memiliki sifat yang senantiasa mengutamakan dirinya sendiri. Ananiyah dilihat dari sudut bahasa berasal dari bahasa Arab maknanya 'Ana' 
yang berarti 'Saya'. berarti Ananiyah maksudnya sifat ego atau egois juga dikenal dengan sifat ingin menang sendiri.

Kedua Ghadab, selain dari ananiyah juga ada sifat Ghadab yang terlihat pada seseorang yang mudah marah. Ghadab maksudnya murka. Ini bermakna seseorang yang mempunyai perilaku ghadab adalah seseorang yang emosional yang sangat sesnsiitif dan mudah marah. Ghadab ini berkaitan dengan watak dan sifat yang kurang sabar yang kemudian mudah terpancing emosinya

Ketiga Gbibah, kemudian ada pula prilaku yang disebut dengan Ghibah yaitu perilaku bergunjing, artinya seseorang yang memiliki kesukaan membicarakan kondisi orang lain di belakang. Sifat dan perilaku ghibah erat hubungannya dengan membicarakan kejelekan orang lain, meskipun yang dibicarakan itu benar atau salah. namun itu tetap ghibah yang nantinya mengantar seseorang mendekati perbuatan fitnah.

Keempat Hasad, perilaku hasad merupakan suatu perasaan tidak senang apabila melihat orang lain memilihi keunggulan, kelebihan ataupun keberuntungan yang melebihi darinya seperti rejeki yang lebih. Pendek kata, hasad adalah seseorang yang memiliki perasaan iri dengki. mereka yang berperilaku hasad selalunya merasakan dirinya yang benar dan juga selalu resah, gelisah dan curiga kepada orang lain.

Kelima Namimah, selanjutnya ada lagi sifat dan prilaku manusia yang disebut dengan Namimah. Yakni orang yang suka mengadu domba. Perbuatan yang menonjol dari sifat ini adalah dengan menyebar fitnah (menggosip) antara seseorang dengan lainnya bahkan adu domba antar satu kelompok dengan kelompok lainnya. Mereka ini biasanya berlaku namimah disebabkan oleh sifat iri dan dengki. Orang yang berperilaku namimah disisi Allah swt akan di murkai. Mereka akan dijauhi oleh teman, sahabat, andai taulan bahkan keluarga.

Dan masih banyak lagi bentuk dan sifat-sifat buruk yang mengidap pada diri seseorang yang tentu tidak dapat diperjelaskan satu persatu dalam pembahasan ini. Yang pasti apapun bentuk perilaku yang bertentangan dengan nilai-nilai kemanusian apalagi ajaran agama Islam, hendaknya diperbaiki. Sehingga semua akan terhindar dari murka Allah swt dan RasulNya.

\section{Faktor Penyebab Akhlak Buruk}

Dalam tafsir Tematik dijelaskan bahwa, maksiat dan dosa merupakan prilaku manusia dalam keseharian mereka (Ali, 1997, p. 619). Manusia biasa tidak terlepas dari prilaku dosa setiap harinya, baik dosa kecil maupun dosa besar, hanya prekuuensinya yang berbeda, kecuali para nabi, karena mereka terpelihara dari dosa (Lajnah Pentashihan Mushaf al-Quran, 2012, p. 151). 
Muncul dan lahirnya sikap yang tidak terpuji saat sekarang, salah satu akibat dari individu yang menerima budaya yang dating dari luar, tanpa ada usaha penyeleksian baik dan buruknya terhadap mereka. Karena mengambil suatu budaya katakanlah itu barat yang tidak sesuai dengan budaya bangsa yang budaya timur, mereka terpengaruh dengan kebiasaan yang buruk melalui berbagai pengaruh baik media elektronik, style, dan gaya hidup yang serba lebih ke modern-modernan. Disisi lain dampak perkembangan teknologi yang beriringan dengan budaya membuat sebagian orang di negeri ini menyalahgunakannya dengan berbagai kemauan dan kehendak mereka sendiri.

Zakiah Derajat (1985) menjelaskan beberapa penyebab terjadinya dekadensi moral atau perilaku buruk khususnya di tanah air, yaitu: Minimnya pembinaan dan pembentukan mental/karakter, minimnya pengenalan terhadap nilai-nilai pancasila, kegoncangan/geger budaya dalam masyarakat, rasa pesimis terhadap masa depan di kalangan pemuda, serta pengaruh budaya asing (p. 48).

Seyogyanya masyarakat turut cerdas dengan perkembangan teknologi dan mampu menapis segala yang menjerumuskan mereka dari budaya yang dapat merusak jati dirinya, mereka dapat memilih dan memilah mana yang baik dan mana pula budaya, teknologi dan lain sebagainya yang bermanfaat dan memiliki kemaslahatan yang positif.

Akhlak yang buruk berasal dari penyakit hati seperti dengki, ujub, sombong, suudzaan (berprasangka buruk), nifaq (munafik), hasud, dan penyakit hati yang lainnya. Akhlak buruk berimplikasi kepada berbagai macam kerusakan baik bagi orang itu sendiri, orang lain maupun kerusakan lingkungan sekitarnya, sebagai contohnya yakni kegagalan dalam membentuk akhlak mulia pada manusia sama seperti mengakibatkan kehancuran pada bumi, sebagai mana firman Allah SW'T dalam Surat Ar-Ruum ayat 41:

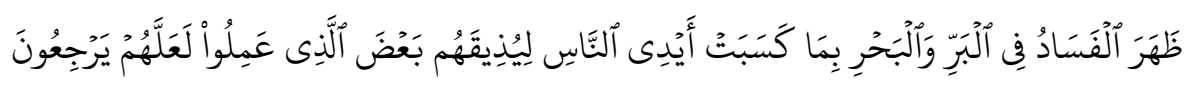

"Telah nampak kerusakan di darat dan di laut disebabkan karena perbuatan tangan manusia, supaya Allah merasakan kepada mereka sebahagian dari (akibat) perbuatan mereka, agar mereka kembali (ke jalan yang benar)".

Dalam satu hadis disebutkan: dari Abdullah r.a. tidak dapat masuk surga seseorang yang terdapat di dalam hatinya kesombongan walaupun hanya seberat biji bayam (Daud, 1993, p. 41). Sebagai seorang muslim yang baik dan beriman dengan ajaran Islam mereka menjauhi dan menghindari pekerjaan dan perkumpulan yang merusak dan tidak bermakna. Oleh sebab itu, Nabi Muhammad saw, sebagaimana yang diriwayatkan oleh Muslim dari hadis Ishaq bin Abdullah bin Abi Talhah menjelaskan bahwa jauhilah oleh kamu majlis-masjlis 'Asyirah dalam lafazh muslim berbunyi: 
"Jauhilah oleh kamu sekalian majlis majelis "Ash'adaa" yang makna kedua sama yaitu pertemuanpertemuan yang digunakan untuk sekedar obrolan mengeluarkan kata-kata kosong atau keji (adDamsyiqi, 2008, p. 38). Tentunya akal dan nurani seorang setiap manusia dapat dilihat melalui kelakuan yang biasa ia tampakkan dalam keseharian. Dengan kata lain, akhlak merupakan satuan ukuran yang digunakan untuk mengukur ketinggian akal dan nurani seseorang. Akhlak akan dimiliki oleh siapa saja yang secara sungguh-sungguh memahami, meyakini, dan mengamalkan ajaran Islam.

\section{Dampak Akhlak Buruk}

Hamka (1983) mengemukakan; kita ini manusia, terjadi daripada jasmani, rohani dan nafsunya; tubuh, nyawa dan nafsu. Kita bukan Malaikat yang semata-mata Rohaniat. Kitapun bukan Iblis yang semata-mata api yang penuh kenafsuan. Tetapi kitapun bukan semata-mata binatang. Sebab kita dapat menimbang mana yang baik, mana yang buruk, mana yang manfaat dan mana yang berbahaya. Kalau terus menerus berbuat maksiat tandanya luka sudah, dia tidak takut lagi kepada azab siksa Allah. Dia sudah diperintah oleh hawa nafsunya dan dilepaskannya dirinya daripada perintah Allah (p. 36).

Dalam salah satu hadis, disebutkan oleh Rasulullah saw, bagaimana menghindari keburukan akhlak, serta memelihara kejahatan yang dilahirkan oleh nafsu.

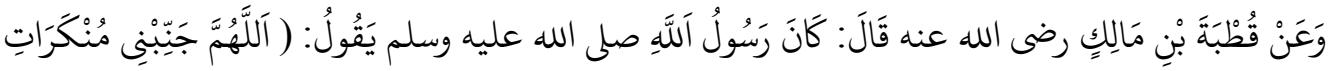

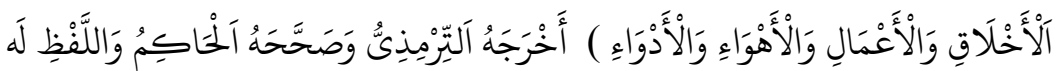

"Dari Quthbah Ibnu Malik Radliyallaahu 'anhu bahwa Rasulullah Shallallaahu 'alaihi wa Sallam bersabda: "Ya Allah jauhkanlah diriku dari kejelekan akhlak perbuatan hawa nafsu dan penyakit." Riwayat Tirmidzi. Hadits shahih menurut Hakim dan lafadz ini menurut riwayatnya" (al-Asqalany, 2008).

Allah SWT dalam firmanNya :

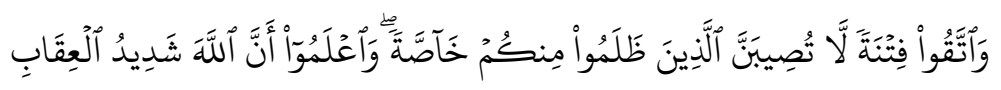

"Dan peliharalah dirimu dari pada siksaan yang tidak khusus menimpa orang-orang yang zalim saja di antara kamu. Dan ketahuilah bahwa Allah amat keras siksaanNya"(QS. Al-Anfal $8: 25)$

\section{Upaya Penanggulangannya}

Akhlak mempunyai tali perhubungan yang akrab dengan iman dan takwa. Tanpa akhlak bermakna iman dan takwa menjadi gersang. Akhlak yang baik yang disarankan oleh alQuran banyak sekali seperti iman, takwa, amal saleh, ikhlas, sabar, amanah, zuhud, adil, suka 
memaaf, pemurah dan sebagainya. Antara sifat-sifat mahmudah yang yang disarankan dalam Islam bagi melahirkan insan yang baik dan berakhlak tinggi sejajar dengan akhlak Rasulullah s.aw (Salleh, 1995, p. 341). Kemudian dijelaskan dalam hadis, tiga perkara yang bagi siapa memilikinya, maka Allah pasti melindunginya dibawah rahmat-Nya (pada hari kiamat) dan akan memasukkannya ke dalam surga, yaitu: Sayang (sopan santun) kepada yang lemah. Kasih saying kepada kedua orang tua. Berlaku baik kepada hamba sahaya (al-Khandalawi, tt, p. 489)

Maka bagi siapa yang iman dan akhlaknya benar dan bertakwa kepada Allah SWT ia akan mendapatkan kebahagiaan. Perbuatan manusia akan dibalas setimpal oleh Allah SWT sesuai dengan apa yang telah mereka lakukan.

Saatnya bagi ummat Islam untuk meninggalkan sikap eksklusifisme dan fanatik kepada golongan tertentu karena ummat Islam saat ini sudah semakin cerdas ditambah lagi sarana informasi yang berkembang pesat, sehingga tidak ada alasan lagi bagi umat Islam untuk tidak mau mempelajari ajaran agamanya sendiri. Ikhlas dalam menjelaskan suatu permasalahan dengan niat supaya ummat beribadah kepada Allah dengan baik dan benar sesuai tuntunan Nabi Muhammad SAW dan para Sahabat Beliau. Berdakwah mengajak manusia kepada Allah dan Rasul-Nya agar selamat di dunia dan di akhirat, dengan penyertaan perubahan sikap dan perilaku yang juga dapat dijadikan rujukan dan diteladani bagi yang lain. Bukan mengajak manusia kepada dirinya, kelompoknya, golongannya atau kepentingannya, melainkan sesuai dengan apa yang telah diperintahkan oleh Yang Maha Kuasa. Belajar ikhlas dan berlapang dada dalam menyikapi perbedaan pendapat selama masih dalam koridor Sunnah saling menghormati, menghindari menfitnah dan memprovokasi karena dalam al-Quran telah disebutkan bahwa umat Islam semua bersaudara dan semoga semua pada akhirnya sama-sama masuk surga, meskipun disisi lain senantiasa ada perbedaan, termasuk amalan dan ibadah Sunnah.

Islam mengajarkan umatnya untuk tidak mudah diprovakasi dengan isu-isu atau berita bohong, bahkan Islam mengajarkan agar umat ini sebelum menerima dan menyebarkan berita tentang sesuatu hendaknya mengetahui dengan jelas, sehingga tidak menimbulkan fitnah. Allah SWT menjelaskan dalam firmanNya :

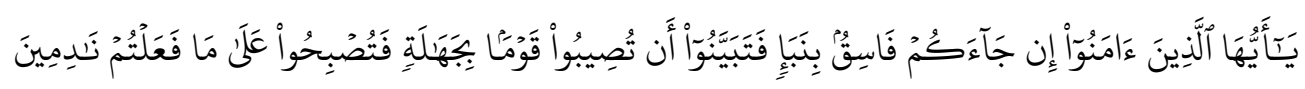

"Hai orang-orang yang beriman, jika datang kepadamu orang fasik membawa suatu berita, maka periksalah dengan teliti agar kamu tidak menimpakan suatu musibah kepada suatu kaum tanpa mengetahui keadaannya yang menyebabkan kamu menyesal atas perbuatanmu itu."(QS. Al-Hujurat : 6). 
Usaha untuk membentuk dan memelihara agar perilaku buruk tidak berkembang, maka perlu disemai rasa dan kekuatan persaudaraan, sehingga setiap individu memeliki ikatan antara yang satu dengan yang lain. Islam telah mengajarkan prinsip-prinsip tersebut, sebagaimana disebutkan dalam hadis Nabi Muhammad saw.

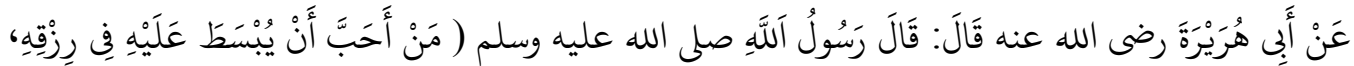

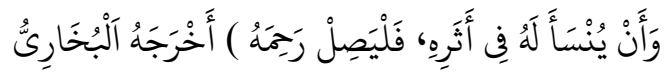

"Dari Abu Hurairah Radliyallaahu 'anhu bahwa Rasulullah Shallallaahu 'alaihi wa Sallam bersabda: "Barangsiapa ingin dilapangkan rizqinya dan dipanjangkan umurnya, hendaknya ia menghubungkan tali kekerabatan." (HR. Bukhari)

Kemudian dijelaskan pula dalam firman Allah SWT

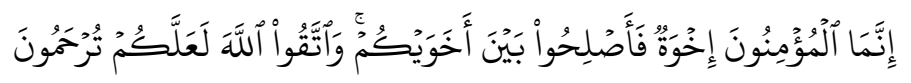

"Orang-orang beriman itu sesungguhnya bersaudara. Sebab itu damaikanlah (perbaikilah hubungan) antara kedua saudaramu itu dan takutlah terhadap Allah, supaya kamu mendapat rahmat."(QS. Al-Hujurat : 10).

Selain itu, juga disebutkan dalam hadis lain, dari Abu Hurairah r.a, dari Nabi saw beliau bersabda; tujuh golongan dilindungi Allah dibawah lindunganNya, waktu tidak ada perlindungan selain perlindungan-Nya: Pertama, imam (Kepala Pemerintahan) yang adil. Kedua, pemuda yang dalam masa mudanya beribadat kepada Allah. Ketiga, orang yang menyebut (mengingati ) Allah ketika sendirian, lalu menetes air matanya. Keempat, laki-laki yang tergantung hatinya di masjid (beribadat). Kelima, orang yang berkasih sayang karena Allah semata-mata. Keenam, laki-laki yang dirayu oleh seorang perempuan bangsawan cantik, tetapi dia mengatakan (menolak) "Sesungguhnya saya takut kepada Allah, orang yang bersedekah dan disembunyikan, sehingga tangan kirinya tidak mengetahui apa yang diperbuat (diberikan) oleh tangan kanannya (Zainuddin Hamidy, 1992, p. 98)

Banyak sekali cara dan sikap yang diajarkan oleh Rasulullah kepada umatnya untuk berbuat baik dan meninggalkan hal-hal yang buruk. Seperti disebutkan dalam sabdanya :

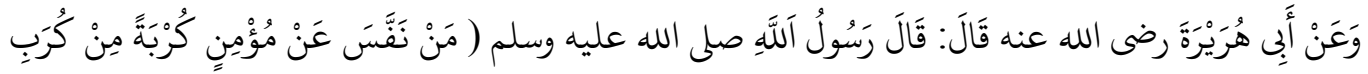

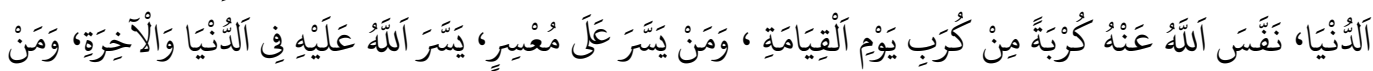

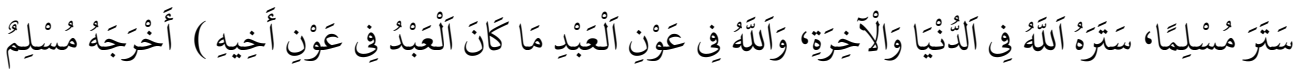

"Dari Abu Hurairah Radliyallaahu 'anhu bahwa Rasulullah Shallallaahu 'alaihi wa Sallam bersabda: "Barangsiapa melepaskan kesusahan seorang muslim dari kesusahan dunia, Allah akan melepaskan kesusahannya pada hari kiamat; barangsiapa memudahkan seorang yang mendapat kesusahan, Allah akan memudahkan urusannya di dunia dan akhirat; dan barangsiapa menutupi (aib) seorang muslim, Allah akan 
menutupi (aibnya) di dunia dan Akhirat; dan Allah selalu akan menolong hambanya selama ia menolong saudaranya" (HR. Muslim).

Dengan mengetahui dampak akhlak yang buruk serta bahaya yang akan muncul darinya, mengakibatkan orang akan berusaha menjauhinya. Akhirnya orang tersebut akan terhindar dari berbagai macam perbuatan yang dapat mencelakakan dirinya sendiri. Dengan demikian ilmu akhlak secara ringkas dapat diformulasikan sebagai ilmu yang bertujuan untuk memberi pedoman kepada manusia agar mengenal dan membedakan perbuatan yang baik atau yang buruk.

Tentu dengan memahami uraian tersebut maka sebagai umat Islam secara khusus dan manusia secara umum mestilah saling menghormati, menghargai antara satu dengan yang lain. Dengan meninggalkan sifat-sifat buruk yang terpendam dalam dirimasing-masing. Bangunlah sikap dan sifat baik sangka sehingga Allah SW'T pun akan berbaik sangka dengan hambanya.

\section{PENUTUP}

Manusia semestinya dapat memahami bahwa ia ciptakan memiliki tujuan hidup. Dengan mengawali memahami keberadaannya dalam sistem penciptaan. Sebagaimana juga alam semesta diciptakan Allah bukan tiada tujuan. Manusia adalah salah satu dari penciptaan alam semesta, dimana alam yang ciciptakan tersebut adalah untuk suatu tujuan. Sebagaimana yang dijelaskan dalam firman Allah SWT dalam surat al-Zariyat ayat 56, Nampak jelas fungsi dan tujuan manusia diciptakan oleh Allah, yakni untuk mengabdikan diri dengan ketentuan dan aturan yang benar. Hal ini untuk menjelaskan kepada manusia bahwa dalam proses dan sistem penciptaannya adalah sebagai hamba Allah SWT. Tentu berkaitan dengan peran yang mesti dipahami oleh manusia untuk melakukan ibadah kepada Allah SWT.

Kegiatan dan perbuatan yang melekat pada manusia tersebut menunjukkan bahwa perbuatan ibadah tidak terbatas pada shalat, puasa, zakat yang biasa disebut ibadah mahdah, tetapi ibadah meliputi segala tindak tanduk serta perbuatan dalam menjalankan peranannya sebagai manusia di muka bumi yaitu diberikan kepercayaan sebagai khalifah Allah. Tindakan moral yang baik dan mulia, merupakan wujud ibadah yang meliputi seluruh kegiatan manusia dalam hidup di dunia ini, baik kegiatan duniawi sehari-hari, bila aktifitas itu dilakukan dengan ikhlas dan niat mengabdi kepada Allah.

\section{DAFTAR PUSTAKA}

ad-Damsyiqi, I. H.-H.-H. (2008). Asbabul Wurud I (10 ed.). (H. S. Salim, Trans.) Jakarta: Kalam Mulia.

al-Asqalany, A.-H. I. (2008). Bulugul Maram min Adilatil Abkaam. Tasik Malaya: Pustaka alHidayah.

Ali, L. (1997). Kamus Besar Bahasa Indonesia. Jakarta: Balai Pustaka. 
al-Khandalawi, M. M. (tt). Muntakhab Ahadits, Tuntuan Sifat-Sifat Mulia Para Sababat Nabi SAW. (M. Sayani, Trans.) Pustaka Ramadhan.

al-Rahlawi, A. A. (1979). Ușul al-Tarbiyah al-islam wa Asälibuha. Beirut: Darl Fikri.

Aulia. (2019). Sahabat. Kerinci: Simpang Belui.

Azwan, H. (1993). Rahasia Mengenal Diri. Selangor: Cita Khidmat.

Daud, M. (1993). Terjemahan Hadis Sabih Muslim. Jakarta: Widjaya.

Hamka. (1983). Iman dan Amal Saleh. Kuala Lumpur: Pustaka Melayu Baru.

Hamka. (1994). Jakarta: Bulan Bintang.

Hasjmy, A. (1994). Dustur Dakwah menurut Al-Quran. Jakarta: Bulan Bintang.

Lajnah Pentashihan Mushaf al-Quran. (2012). Tafsir al-Quran Tematik, Spritualitas dan Akblak. Jakarta: Aku Bisa.

Lari, S. M. (2006). Etichs and Spritual Grawth. (A. M. D, Trans.) Bandung: Pustaka Hidayah.

Madjid, N. (1993). Beberapa Renungan tentang Kehidupan Keagamaan untuk Generasi Mendatang. Jurnal Kebudayaan dan Peradaban Ulumul Quran, 4, 1.

Mahjudin. (1991). Kuliah Akblak-Tasawuf. Jakarta: Kalam Mulia.

Natsir, M. (2000). Fiqhud Dakwah. Jakarta: Yayasan Capita Selekta.

Nawawi, H. (1993). Pendidikan Dalam Islam. Surabaya: Al-Ikhlas.

Salleh, A. b. (1995). Pendidikan Islam, Dinamika Guru (Vol. 3). Selangor: Fajar Bakti.

Salmadanis. (2004). Da`i dan Kepemimpinan . Jakarta.

Sunata, I. (2017). Konsep Dakwah dalam Memelihara dan Pemberdayaan Masyarakat di Sekitar Hutan (Studi Kasus di Kabupaten Kerinci). Jurnal Dakwah dan Komunikasi, 2, 2, 43-57.

W.J.S Poerwadarminta, :. (1976). Kamus Besar Bahasa Indonesia. Jakarta: Balai Pustaka. Zainuddin Hamidy, d. (1992). Terjemah Hadist Shahih Bukhari. Jakarta: Widjaya.

Zakiah Derjat, J. :. (1985). Membina Nilai Moral di Indonesia. Jakarta: Bulan Bintang. 